Writing in Limbo 
ALSO BY SIMON GIKANDI

Reading the African Novel

Reading Chinua Achebe: Language and Ideology in Fiction 


\section{Writing in Limbo}

MODERNISM AND

CARIBBEAN LITERATURE

Simon Gikandi

CORNELL UNIVERSITY PRESS

ITHACA AND LONDON 
Open access edition funded by the National Endowment for the Humanities/ Andrew W. Mellon Foundation Humanities Open Book Program.

\section{Copyright (C) 1992 by Cornell University}

All rights reserved. Except for brief quotations in a review, this book, or parts thereof, must not be reproduced in any form without permission in writing from the publisher. For information, address Cornell University Press, Sage House, 512 East State Street, Ithaca, New York 14850, or visit our website at cornellpress.cornell.edu.

First published 1992 by Cornell University Press.

\section{Library of Congress Cataloging-in-Publication Data}

Gikandi, Simon.

Writing in limbo : modernism and Caribbean literature / Simon Gikandi. p. cm.

Includes bibliographical references and index.

ISBN-13: 978-0-8014-2575-2 (cloth) - ISBN-13: 978-1-5017-1990-5 (pbk.)

1. Caribbean fiction (English)-History and criticism. 2. Modernism (Literature) - Caribbean Area. 3. Carpentier, Alejo, 1904- Siglo de las luces. I. Title.
$823-\mathrm{dc} 21$
$91-23284$

The text of this book is licensed under a Creative Commons Attribution-NonCommercial-NoDerivatives 4.0 International License: https://creativecommons.org/licenses/by-nc-nd/4.0/ 
For Jamie McDonald 
